\title{
Makassar Language Empowerment on the Use of Indonesian Language in Non-Formal Communication
}

\begin{abstract}
Asriani Abbas
Cultural Science Faculty, Hasanuddin University

Email: asriani.abbas@unhas.ac.id

ABSTRACT

Ethnic Makassar includes multilingualism, namely using Makassar language as an intra-ethnic language and Indonesian as an inter-ethnic language. As a local language, the Makassar language functions as a local identity that integrates with Indonesian in non-formal communication. Furthermore, Indonesian was born from the embryo of the Malay language which was raised to its status as a national language. As the national language, Indonesian is used as the state language. In carrying out its function as the state language, the government makes efforts to standardize the Indonesian language so that it can be used in an orderly manner informal communication. This discussion focuses on the function of the Makassar language like a local language and Makassar City government policies related to the empowerment of the Makassar language in the context of preserving the nation's culture. The source of the data is the utterances of respondents who are domiciled in Makassar City and Gowa Regency as many as twenty people who were selected purposively. They have status as employees, teachers, junior and senior high school students, and students. Data collection uses interview, recording, note-taking, and document review techniques. The data is formulated descriptively according to the facts of the language that has been used by the supporting community. The results of this research showed that the Makassar language affected Indonesian, especially on the morphological aspects, namely the presence of clitics and time markers. The Makassar City Government always preserves and empowers the Makassar language such as regular meetings related to local culture, re-activating cultural inheritance local culture, and improving the guidance and development of local culture in Makassar City.
\end{abstract}

Keywords: Makassar ethnicity, Makassar language, Indonesian language.

\section{INTRODUCTION}

Indonesia has about 750 local languages, including the Makassar language. It is a part of the mosaic of Indonesian culture which is the nation's cultural proverty that is protected by law and should be preserved. Makassar language is used as a mother tongue for its speakers as a differentiator between one ethnicity and another. It is carrying out its functions to improve the national language whose existence is recognized by the state as in Article 32 paragraph 2 of the 1945 Constitution which reads "The state respects and preserves regional languages as national cultural treasures."

The Makassar ethnic, known as the Makassar tribe, inhabit the west coast of the South Sulawesi peninsula. Ethnic Makassar includes multilingualism, namely using Makassar language as an intra-ethnic language and Indonesian as an inter-ethnic language. As a local language, the Makassar language has functioned as a local identity and integrates with Indonesian in non- formal communication. Furthermore, Indonesian was born from the embryo of the Malay language which was elevated to the status of the national language. As the national language, Indonesian is used as the state language.

Thus, coexistence between the Makassar language and the Indonesian language creates mutual influence, both from the phonological, morphological, and syntactic aspects, also the influence of vocabulary. The mutual influence between the two languages indicates that the two languages are flexible which leads to positive values. The positive value in question is related to the ability of the two languages to carry out their respective functions. The Makassar language functions as a means of expressing Makassar culture, as a marker of Makassar ethnic identity, as part of the cultural mosaic, as a bridge between generations, and as a supporter of the national language. Likewise, Indonesian has two positions, namely as the national language and as the state language following the 1945 
Constitution. In addition, Indonesian plays a role as a source of knowledge.

Concerning the Makassar language, Indonesian is used in two varieties, namely the informal and formal varieties. In informal situations, the presence of regional languages, especially the Makassar language can participate as a messenger, while in the formal variety Indonesian has undergone standardization as the basis for standardizing the Indonesian language informal communication. These two varieties are used competitively according to their respective domains.

The discussion of this article focuses on the influence of the Makassar language on the use of the Indonesian language and the Makassar City government's policy regarding the empowerment of the Makassar language in the context of preserving the nation's culture. However, it should be acknowledged that in this era of globalization, the Indonesian people are faced with a very dilemmatic condition, especially from the linguistic aspect. A foreign language as a means of communication, especially in the realm of modern science and technology, is a priority. The use of good and correct Indonesian is being promoted. On the other hand, the local languages and literature need to be fostered and preserved as one of the local cultural assets. The solution that should be taken is to place the position of each language according to its function. Makassar language can be empowered in the use of Indonesian as a medium of non-formal communication. Furthermore, Indonesian can be standardized for formal communication purposes. Likewise, foreign languages can function as a medium to acquire knowledge and increasingly modern technology.

\section{METHODOLOGY}

The data source is the speech of respondents who live in Makassar City and Gowa Regency when they interact in non-formal situations. Twenty respondents were selected purposively. They are employees, teachers, junior and senior high school students, and university students. The data was collected using the field method to obtain the information needed to achieve the research objectives. The data were collected using interview, recording, note-taking, and document review techniques. The data used is sourced from oral data in the form of Indonesian speech in the Makassar dialect. The recording technique is carried out to obtain as much data as possible when Makassar speakers speak Indonesian in various situations. The recorded speakers know no age limit. The main point for the speaker is at least bilingual, that is, mastering the Makassar language and Indonesian. The note-taking technique was used to record many Indonesian utterances which were influenced by the dialect of Makassar. The document review is needed to provide information related to the government's efforts to empower the Makassar language for the use of Indonesian and as a lingua franca for speakers who live in Makassar as well as speakers from outside the city of Makassar, even for speakers from abroad.

The data collection technique used is unlimited random sampling, which is comprehensive sampling. All belonging to the Makassar dialect of Indonesian were identified without specifying the number and type. In other words, data is collected randomly regardless of the type and amount of data obtained in the field. If the data collected has the same form, limited data will be displayed which is expected to represent the entire available data. The data were analyzed descriptively to provide information to the reader about Makassar linguistic facts that affect the Indonesian language. A clear description of the data will provide comprehensive linguistic information to speakers of different ethnicities, both domiciled and visiting Makassar City and its surroundings.

\section{ANALYSIS}

\subsection{Indonesian in Informal Communication}

Makassar language that coexists with Indonesian causes language contact. The habit of using two languages in a speech community by (Izzak, [1]) is referred to as a bilingual society. Moreover, Chaer et al. [2] say that bilingualism occurs when the speech community is open to other speech communities. In this regard, Indonesian which is in contact with the Makassar language produces the Makassar dialect of Indonesian.

The existence of the Makassar language also contributes to the role of Indonesian as a medium for conveying information in social life. When contact between Indonesian and Makassarese occurs, of course, it will lead to code-switching consequences. Appel [2]) defines code-switching as a symptom of switching language use due to changing situations. A language situation like this will result in interference which, according to Nababan [3] is an error that occurs as a result of carrying the speech habits of the mother tongue or dialect into a second language or dialect.

According to Spolsky [4], interference is divided into two, namely internal interference and external interference. For example, internal interference is found in the simultaneous use of Makassarese and Indonesian languages, while external interference is found in the use of Indonesian and English. The interference mentioned in the first section occurs positively because it is used as a messenger in informal communication. Informal communication will take place in a friendly, relaxed, and familial manner if the Makassar language is also empowered in various aspects of the life of the people who speak it. In fact, the influence of the Makassar language on Indonesian has become a lingua franca for its speakers, both from outside the city of Makassar and from abroad.

Interference can cover various linguistic aspects such as sound system (phonology), word formation 
(morphology), and sentence structure (syntax). Jendra [8] distinguishes interference into five linguistic aspects, including (1) interference in the system field or sound system (phonology); (2) interference in word form (morphology), (3) interference in sentence structure (syntax), (4) interference in vocabulary (lexicon), and (5) interference in the field of meaning (semantics). Among the five types of interference that have been mentioned, interference from the dominant morphological aspect occurs between the Makassar language and the Indonesian language. The linguistic fact that marks the relationship between Makassarese and Indonesian is the participation of personal pronouns, both in free and bound forms, known as clitics. According to Verhaar [5], all short forms that rely on basic forms of language can be categorized as clitics. In sentence construction, first formed verbs undergo pronoun arrangement, either through free pronouns or bound pronouns (clitics). Abbas [6] also explained the arrangement of pronouns (clitics) in the Makassar language, which consists of proclitics and enclitics. A clitic attached to a verb (preverb) is called a proclitic, while a clitica attached to a verb (post verb) is called an enclitic. proclitic $k u$ - refers to pronoun I derived from the free pronoun nakke 'I', proclitic $n u-/ k i$ refers to pronoun II which comes from the free pronoun kau and katte 'you', and proclitic na-refers to pronoun III which comes from the free pronoun dia 'he/she', while the forms $-a k$ 'I', $-k o$ 'you/- $k i$ 'you', $-i$ 'dia' as enklitika.

In the Makassar ethnic, the use of Indonesian which involves the Makassar dialect has certain purposes. The morphological integration of the Makassar language in Indonesian is manifested in the presence of persona markers that contain politeness values with a higher degree of politeness than politeness in Indonesian [7]. It must be acknowledged that Makassar culture upholds the slogans of sipakatau or 'mutual respect', siri' 'selfrespect/shame', and pacce 'joining other people's distress'. This character is realized in polite behavior, high solidarity, responsibility, and firm stance [9]. Furthermore, Indonesian functions are a local identity, a symbol of regional pride, a means of communication within the family and local community, as a supporter of the national language, and as the language of instruction in elementary schools in certain areas at the initial level to facilitate teaching.

\subsection{The Effect of Makassar Language on Indonesian in Non-Formal Communication}

Speech in non-formal Indonesian can be seen in the use of clitics. Some are proclitic and some are enclitic according to the following example

1. Proclitic $k u$ - 'me', nu- 'you', ki- 'you', and -na 'he/she'

(1) I eat your bread.

(1a) Kumakangi rotinu.
(2) You eat her bread.

(2a) Numakangirotina

(3) You eat your bread.

(3a) Kimakangi rotina

(4) He eata your bread.

(4a) Namakangi rotinu

The utterances in examples (1), (2), (3), and (4) use formal Indonesian. Meanwhile, examples (1a), (2a), (3a), and (4a) use the Makassar dialect of Indonesian. The speech 'eat' in Indonesian is marked by the presence of proclitic $k u$ - 'I', $n u$ - 'you', $k i$ - 'you', $n a-$ 'he/she' as personal pronouns I, II, III in Makassar language. These four sentences provide information to the speech partner that the speaker is doing the activity of 'eating' which is marked by enklitika $-i$. The verb's enclitics function as absolute markers that refer exophorically to the accompanying object, namely 'bread'.

In example (2a), there is a familiar form of $n u$ - 'you'. Furthermore, in example (3a) there is a proclitic of persona II $k i$ - 'you/sir' which is honorific (polite). The presence of the clitic indicates that some Makassarese pronouns are in the familiar form and some are in the honorific form (polite).

2. Enclitic -ak- 'me', -ko 'you', -ki 'you', and -na 'he/she'

(5) I eat the bread.

(5a) Makangak roti.

(6) You eat the bread.

(6a) Makanko.

(7) You eat the bread.

(7a) Makanki roti.

(8) He eats the bread.

(8a) Makangi roti.

The utterances in examples (5), (6), (7), and (8) use formal Indonesian. Meanwhile, examples (5a), (6a), (7a), and (8a) use the Makassar dialect of Indonesian. The four sentences are marked by the presence of enclitics - $a k$ 'I' (5a), - $k o$ 'you' (6a), - $k i$ 'you' (7a), and $-i$ 'he/she' (8a) as personal pronouns I, II, III in Makassar language. These sentences provide information to the speech partner that the speaker is doing the activity of 'eating'.

The presence of proclitics and enclitics in verbs requires absolute markers $-i$. The absolute markers $-i$ refer exophorically to the object of the sentence. Both types of clitics are very productive and systemic in the Makassar dialect of Indonesian. 


\section{Enclitic -ma as Market of Past Time}

The - ma marker can integrate with the enclitics $-a k$, $-k o,-k i$. $-i$ which contains the meaning of work that has been done and is still ongoing, such as:

$$
\begin{aligned}
& \text { ma- }+-a k \rightarrow-m a k \\
& m a-+-k o \rightarrow-m a k o \\
& m a-+-k i \rightarrow-m a k i \\
& m a-+-i \rightarrow-m i \\
& \text { Examples: } \\
& \text { (9) I have studied. } \\
& \text { (9a) Belajarmak. } \\
& \text { (10) You have studied. } \\
& \text { (10a) Belajarmako } \\
& \text { (11) You have studied. } \\
& \text { (11a) Belajarmaki. } \\
& \text { (12) He has studied. } \\
& \text { (12a) Belajarmi. }
\end{aligned}
$$

The utterances in examples (9), (10), (11), and (12) use formal Indonesian. Meanwhile, examples (9a), (10a), (11a), and (12a) use Makassar dialect of Indonesian. The four sentences are marked by the presence of enklitika -mak 'already me' (9a), -mako 'already you' (10a), -maki 'already you' (11a), and -mi 'already he' (12a) as personal pronouns I, II, III in Makassar language. These sentences provide information to the speech partner that the learning activity has been carried out and is still ongoing. In the context of a different sentence in the sentence: Makanmi! The -mi marker attached to the word 'eat' can mean inviting people to eat food that has been prepared by the speech partner.

\section{Enclitic -ja as Current Time Marker}

The -ja marker can integrate with the enclitics $-a k$, $k o$, $-k i$. $-i$ (Pronouns I, II, and III) which contain the meaning of ongoing work and mean seriousness such as:

$$
\begin{aligned}
& -\mathrm{ja}+-\mathrm{ak} \rightarrow-\mathrm{jak} \\
& -j a+-k o \rightarrow-j a k o \\
& -j a+-k i \rightarrow-j a k i \\
& -j a+-i \rightarrow-j i
\end{aligned}
$$

Examples:

(13) I am already studying.

(13a) Belajarjak.

(14) You are already studying.

(14a) Belajarjako.

(15) You are already studying.

\section{(15a) Belajarjaki.}

(16) He is already studying.

(16a) Belajarji.

The utterances in examples (13), (14), (15), and (16) use formal Indonesian. Meanwhile, examples (13a), (14a), (15a), and (16a) use the Makassar dialect of Indonesian. The four sentences are marked by the presence of enclitic -jak 'yes it's me' (13a), -jako 'yes it's you' (14a), -jaki 'yes it's you' (15a), and -ji 'yes it's him' (16a) as personal pronouns I, II, III in the Makassar language. These sentences provide information reinforcement to the speech partner that the learning activity has been carried out.

\section{Enclitic -pa as Future Time Marker/ Future Progressive Time}

The - $p a$ marker can integrate with the enclitics $-a k$, $-k o$, $-k i,-i$ (Pronouns I, II, and III) which contain the meaning of work for the progressive future time and have the meaning of affirmation such as:

$$
\begin{aligned}
& -\mathrm{pa}+-\mathrm{ak} \rightarrow-\mathrm{jak} \\
& -p a-+-k o \rightarrow-j a k o \\
& -p a+-k i \rightarrow-j a k i \\
& -p a+-i \rightarrow-j i
\end{aligned}
$$

Examples:

(17) I will be studying later.

(17a) Belajarpak

(18) You will be studying later.

(18a) Belajarpako

(19) You will be studying later.

(19a) Belajarpaki.

(20) He will be studying later.

(20a) Belajarpi.

The utterances in examples (17), (18), (19), and (20) use formal Indonesian. Meanwhile, examples (17a), (18a), (19a), and (20a) use Makassar dialect of Indonesian. The four sentences are marked by the presence of enklitika -pak 'later I study' (17a), -pako 'later you' (18a), -paki 'later you' (19a), and -pi 'later he/she' (20a) as pronouns persona I, II, III in Makassar language. These sentences provide information to the speech partner that the learning activity will be carried out.

\subsection{Makassar City Government Policy on Makassar Language Empowerment}

In the context of preserving the nation's culture, the Makassar City Government always preserves and empowers the Makassar language. Various policies that have been implemented include are holding regular meetings related to local culture, reactivate local 
cultural heritage, improving the guidance and development of local culture in Makassar City, providing awareness to residents to continue to understand the local language and literature, understand the position of local language and literature as one of the special education systems in the city of Makassar which is bilingual even multilingual, activate local cultural inheritance activities that contain noble meaning, both through family channels and education channels; improve the guidance and development of local culture by way of inventorying, collecting, identifying, and processing local texts and wisdom; holding regular meetings in the form of seminars, dialogues, workshops related to local culture (language and literature), manage pluralism in addition to religion and culture also local traditions as a force to glue of integration among each other. The government also built enthusiasm in the community to always use the local language, be tolerant, and sympathize integrally in social behaviour.

Makassar City government policy is a concrete way to preserve the Makassar language. It is a great demand by various tribes who live and visit Makassar. It has become a lingua franca or social language in daily life by the supporting community. In addition, the Makassar language has functioned as a local identity, a symbol of regional pride, a means of communication within the family and the local community.

\section{CONCLUSION}

Indonesian is the language of unity that is understood by Indonesian citizens. For the majority of Indonesian people, Indonesian is not only used as a mother tongue but most of them also use their respective local languages to communicate in their daily life. They often confuse Indonesian with local dialects or accents. In daily communication, people who live in Makassar and its surroundings usually use Indonesian mixed with the Makassar dialect. This combination gave birth to a Makassar dialect of Indonesian which is unique. Its uniqueness is marked by the presence of a bound element in the form of clitics. There are clitics in the form of personal pronouns and some in the form of particles. Clitics derived from personal pronouns consist of neutral or familiar pronouns and honorific pronouns. The clitics can function as affirmations. In addition, clitics can be accompanied by time markers that contain different meanings such as a meaning of work that has been done (perfective), work in progress (present), and work to be done (future perfective). Clitics that have different functions can be attached to the class of nouns, verbs, adjectives, numerals by carrying different meanings according to the context of the speech. Understanding the presence of clitic and time markers in communication situations will make it easier for migrants, both from around South Sulawesi and from abroad, to adapt to the local community.

\section{REFERENCES}

[1] Izzak Arif, 2009. Bilingualisme dalam Perspektif Pengembangan Bahasa Indonesia. Mabasan-Vol. 3. No. 1.

[2] Chaer, Abdul. 2014. Linguistik Umum. Jakarta: Rineka Cipta

[3] Nababan, P.W.J. 1984. Sosiolinguistik Suatu Pengantar. Jakarta: PT Gramedia Utama

[4] Spolsky, Bernald. 1998. Sociolinguistics. New York: Oxford University Press.

[5] Verhaar, J.w.M. 1978. Pengantar Linguistik Umum. Yogyakarta: Gadjah Mada University Press.

[6] Abbas, Asriani. 2014 Perilaku Morfosintaksis Verba Bahasa Makassar. Dissertation of Post Graduated. Makassar: Universitas Hasanuddin.

[7] Kaharuddin, Nurhayati, and Asriani Abbas. 2020. Dialek Makassar sebagai Penanda Kesantunan dalam Berbahasa Indonesia. A Research Report. Makassar: LP2M Unhas.

[8] Jendra, I Wayan.1991. Dasar-Dasar Sosiolinguistik. Denpasar: Ikayana.

[9] https://indtimes.com. "Prinsip Hidup, Kesantuan, dan Kelembutan Hati Suku Makassar Sulawesi Selatan dalam Khasanah Kearifan Budaya lokal sebagai Sumber Pembelajaran." Accessed on September 25, 2021 at 10.28 a.m. 